\title{
BMJ Open Technical capacities needed to implement the WHO's primary eye care package for Africa: results of a Delphi process
}

\author{
Ada Aghaji (D) , ${ }^{1,2}$ Helen E D Burchett (D) , ${ }^{3}$ Wanjiku Mathenge, ${ }^{4}$ \\ Hannah Bassey Faal, ${ }^{5,6}$ Rich Umeh, ${ }^{2}$ Felix Ezepue, ${ }^{2}$ Sunday Isiyaku, ${ }^{7}$ Fatima Kyari, ${ }^{8}$ \\ Boateng Wiafe, ${ }^{9}$ Allen Foster, ${ }^{1}$ Clare E Gilbert ${ }^{1}$
}

To cite: Aghaji A, Burchett HED, Mathenge $\mathrm{W}$, et al. Technical capacities needed to implement the WHO's primary eye care package for Africa: results of a Delphi process. BMJ Open 2021;11:e042979. doi:10.1136/ bmjopen-2020-042979

- Prepublication history and supplemental material for this paper is available online. To view these files, please visit the journal online (http://dx.doi. org/10.1136/bmjopen-2020042979).

Received 24 July 2020 Revised 18 February 2021 Accepted 25 February 2021
Check for updates

(C) Author(s) (or their employer(s)) 2021. Re-use permitted under CC BY-NC. No commercial re-use. See rights and permissions. Published by BMJ.

For numbered affiliations see end of article.

Correspondence to

Dr Ada Aghaji;

aaghaji@yahoo.co.uk

\section{ABSTRACT}

Objective The aim of the study was to establish the technical capacities needed to deliver the WHO African Region's primary eye care package in primary healthcare facilities.

Design A two-round Delphi exercise was used to obtain expert consensus on the technical complexity of each component of the package and the technical capacities needed to deliver them using Gericke's framework of technical feasibility. The panel comprised nine eyecare experts in primary eyecare in sub-Saharan Africa. In each round panel members used a 4-point Likert scale to indicate their level of agreement. Consensus was predefined as $\geq 70 \%$ agreement on each statement. For round 1, statements on technical complexity were identified through a literature search of primary eyecare in sub-Saharan Africa from January 1980 to April 2018. Statements for which consensus was achieved were included in round 2 , and the technical capacities were agreed.

Results Technical complexity statements were classified into four broad categories: intervention characteristics, delivery characteristics, government capacity requirements and usage characteristics. 34 of the $38(89 \%)$ statements on health promotion and 40 of the $43(93 \%)$ statements on facility case management were considered necessary technical capacities for implementation.

Conclusion This study establishes the technical capacities needed to implement the WHO Africa Office primary eye care package, which may be generalisable to countries in sub-Saharan Africa.

\section{INTRODUCTION}

\section{Scope of the problem}

Estimates from sub-Saharan Africa (SSA) indicate that about 22 million people are blind or visually impaired, mainly from avoidable causes such as cataract and uncorrected refractive errors. In addition, over 100 million older adults in SSA are estimated to have near visual impairment. ${ }^{1}$ The age standardised prevalence of blindness ( $\geq 50$ years) is highest of all world regions, being in $5.1 \%$ in western and $4.3 \%$ eastern $\mathrm{SSA},{ }^{2}$ with $80 \%$ of causes being preventable or treatable. Much of the
Strengths and limitations of this study

- This is the first study to establish the technical capacities needed to implement primary eye care in sub-Saharan Africa.

- A recognised technical feasibility framework was used, and statements were derived from a literature review of primary eye care in sub-Saharan Africa.

- A Delphi exercise was used to garner expert opinion and to reach consensus.

- Our expert panel was a non-random sample, and this may have led to hidden biases as the participants may not be representative of all the experts with the predetermined inclusion criteria.

regional variation in prevalence is explained by variability in access to eye care. ${ }^{3}$

Although there are limited data on regional estimates for non-visually impairing conditions (NVICs) in SSA, such as allergic/infective conjunctivitis and dry eye syndrome, the prevalence of NVICs in Kenya and Nigeria are estimated to be $15 \%$ and $25 \%$, respectively. ${ }^{45}$ These figures suggest a high need for eye care services in SSA, yet only $30 \%$ of Africans have access to eye care. ${ }^{6}$

\section{Primary eye care in SSA}

The inclusion of PEC in primary healthcare (PHC) has been recommended as a strategy to increase sustainability and access to eye care services, ${ }^{78}$ and there is global and regional support for PEC. ${ }^{9}$ Indeed, the WHO, in their Global Action Plan 2014-2019, reiterates the importance of accessible eye care services for the effective control of blindness and visual impairment and calls on member states to secure the inclusion of PEC within PHC. ${ }^{10}$ However, a literature review of PEC in SSA reported many challenges to the effective implementation of PEC. These include a lack of agreement on the scope of PEC and a lack of clear guidelines on the technical 
eye-related skills required by PHC workers; these affect the extent of training, supervision and the type of equipment and consumables required. ${ }^{11}$ In response to this, the WHO Africa Office (WHO AFRO) recently developed and pilot tested a package of interventions for PEC in SSA. The WHO AFRO PEC package consists of eight elements that cover two broad areas, that is, health promotion and facility-based case management. ${ }^{12}{ }^{13}$ For health promotion, the package has (two elements): (1) four sets of health messages for healthy people, people at risk of and with eye diseases, for children and carers, those aged 40 years and above, people of all ages and those with diabetes and (2) instructions on how to give a health talk. For facility-based case management the package has six elements: (1) five evidence-based algorithms for red eye, eye swelling, trauma, vision loss for distance and near and children $0-5$ years, (2) a set of 12 evidence-based protocols covering five topics: how to measure visual acuity, how to cover an eye, medication, referrals and removal of foreign bodies, (3) a training package (curriculum and materials), (4) core lists of essential consumables, technologies and medicines, (5) a set of 10 standards and indicators for monitoring and evaluation and (6) templates to collect health information, monitoring and evaluation. Although this health initiative has the potential to increase coverage of eye health services in SSA, ${ }^{8}$ not all health initiatives proposed may be feasible to implement. Feasibility research can help identify the challenges as well as opportunities in implementing a new health initiative. This is particularly true for the WHO AFRO subregion where there is a marked variability in the ability of the 47 member states to implement additional interventions within PHC. ${ }^{14}$

Feasibility in relation to health initiatives is a multifaceted construct that Snowdon described as having the following components: technical, political, cultural, financial and legal feasibility ${ }^{15}$; the technical feasibility component was selected for this study. Technical feasibility is a balance between how complex the intervention is and the technical capacities required to implement it. ${ }^{16}$ The WHO AFRO PEC package has many different technical components, and the overall purpose of this study was to assess the feasibility of integrating the package into PHC in SSA. In this paper, we report the processes involved in developing the content of the feasibility framework for PEC for use in PHC settings in SSA countries.

\section{METHODS}

Our approach was framed by awareness of the limited published literature on the effectiveness of PEC in SSA ${ }^{11}$ and the need to adopt a systematic method to provide expert consensus on the feasibility of implementing PEC to guide policy makers. Against this backdrop, we used a combination of methods: literature reviews (of feasibility frameworks for public health interventions and of PEC in SSA) and a Delphi process. The Delphi method is an iterative method of collecting opinions from a group of experts where evidence from other more robust sources is not available. It uses a series of questionnaires, and responses are modified based on feedback. ${ }^{17}$ The Delphi process has been used in a wide variety of research areas, including health research. ${ }^{18}$ The classic Delphi process is characterised by: (A) anonymity of the participants to each other, which encourages free expression of opinion, (B) iteration, (C) controlled feedback from the group and (D) statistical aggregation of the group response. ${ }^{18}$

\section{Step 1: Delphi questionnaire development}

The WHO AFRO PEC package was divided into two components: eye health prevention/promotion and case management. An appropriate technical feasibility framework was identified by searching PubMed from January 2000 to April 2018 using the search terms 'technical feasibility' and 'frameworks'. The titles and abstracts of articles identified by the search strategy were screened, and potential full-text articles were reviewed by a single author (AA) (figure 1A) (see online supplemental material: appendix 1$)$.

The conceptual framework to evaluate the technical complexity of public health interventions selected for this study, which was developed by Gericke et $a l^{16}$ has four dimensions: basic characteristics of the intervention, delivery characteristics, government capacity/ need for regulation or legislation, and usage characteristics $^{16}$ (table 1). Gericke's framework has been used to determine the technical complexity of condom social marketing for the prevention of HIV/AIDS and other sexually transmitted diseases ${ }^{16}$ and to assess aflatoxin risk reduction strategies in Africa, for example. ${ }^{19}$ For an intervention to be deemed feasible, the technical capacity must match the technical complexity of the intervention, thus intervention complexity complements the concept of institutional capacity. ${ }^{16}$

The WHO AFRO PEC package was divided into two components: eye health prevention/promotion and case management. The four dimensions of Gericke's framework were applied to each component, that is, intervention characteristics, delivery characteristics, government capacity requirements and usage characteristics.

To populate the framework, a literature search on PEC in SSA was conducted, and all articles of PEC in SSA up to April 2018 were searched for using MEDLINE. Search terms included 'primary eye care', with 'sub Saharan Africa' and 'eye disease' or 'eye' with 'primary healthcare' and 'Africa'. ${ }^{11}$ In addition, we used all the relevant articles from the two most recent published reviews on PEC in $\mathrm{SSA}^{1120}$ to identify evidence-based criteria for the technical complexities required to implement each component of the WHO AFRO PEC package (figure 1B).

Further implementation characteristics were identified by two of the authors (CEG and AA) who have more than 40 years combined experience of eye care in SSA. This yielded a list of key criteria for the technical complexity of PEC. A 4-point Likert scale (where 1=strongly agree and $4=$ strongly disagree) was applied to each of the 
A

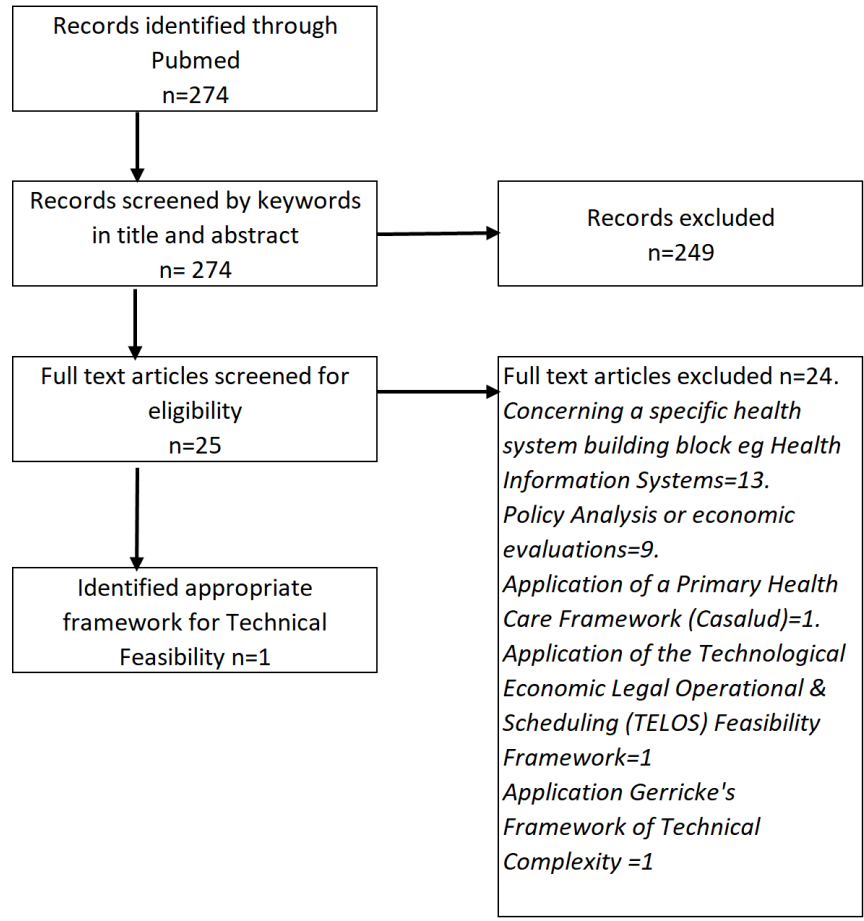

B

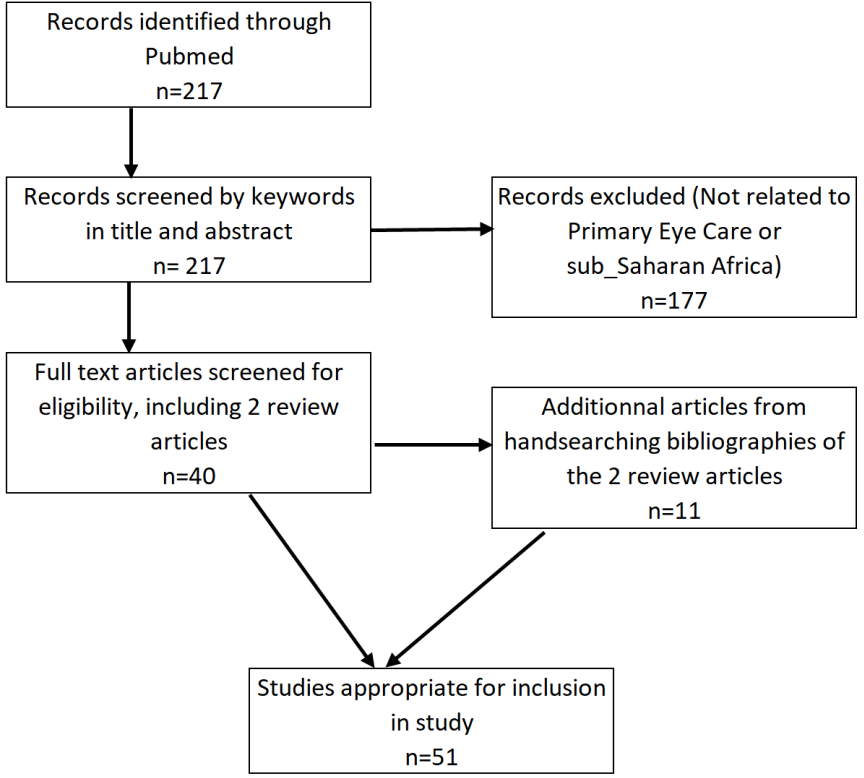

Figure 1 Literature searches for (A) technical feasibility framework and (B) primary eye care in sub-Saharan Africa. statements, and this formed the Delphi questionnaires. The Delphi questionnaires were reviewed by an expert in international eye health (CEG), a health interventions expert (HEDB) and a statistician (DM). They were then sent to a panel of experts in PEC in SSA.

\section{Step 2: selection of experts for the Delphi exercise}

The aim was to recruit a panel of eye care professionals who were experts in eye care in SSA, with expertise to validate the relevance of the selected technical complexities and capacities required to implement the WHO AFRO PEC Package. Eligibility criteria included an eye care professional with a minimum of 10 years' experience of community eye care in SSA, still professionally active and with experience of eye health policy. They were selected by a modified exponential snowball sampling method where an initial participant provides multiple referrals. ${ }^{21}$ Each new referral was vetted and included in the study if the eligibility criteria were met. Two of the authors AA and CEG selected the initial participants, and these participants nominated others based on the stated eligibility criteria.

\section{Step 3: Delphi round 1}

Members of the team were contacted by email and telephone, and their availability was confirmed. Written informed consent was obtained. Members were sent the following documents: the methods to be used during the Delphi exercise, an explanation of Gericke's framework of technical complexity and a draft of the technical complexities required to deliver both components of the WHO AFRO PEC package in the form of the first Delphi questionnaires. Participants were invited to state their level of agreement to each statement in the questionnaire by ticking the appropriate level in the Likert scale in a Microsoft Excel spreadsheet. A comments box was included beside each statement for comments or suggestions.

\section{Step 4: analysis of Delphi round 1}

Once all the questionnaires had been received, they were analysed for consensus. Analyses were performed using STATA V.15.1 (Statcorp, Texas, USA) to generate descriptive statistics. No universally accepted criteria for consensus have been defined for Delphi studies. ${ }^{22}$ However, it has been shown that consensus can be said to have been achieved if a certain proportion of the votes fall within a predefined range. ${ }^{23}$ Consensus for this study was defined as at least $70 \%$ agreement on each statement in the upper 50th percentile (Likert scores 1 and 2 ). Where consensus was reached, the statements were adopted. Statements where consensus was not reached were modified based on the suggestions/comments and incorporated into the second round, as were newly identified statements.

\section{Step 5: modification for technical capacity}

Statements included from the first round were modified so that panel members could indicate their agreement on the technical capacities, which need to be available to deliver the WHO PEC package. 
Table 1 Technical feasibility framework of Gericke

\section{Gericke's framework}

Category Criteria

Basic product design Stability.

Standardisability.

Safety profile.

Ease of storage.

Ease of transport.

\begin{tabular}{|c|c|}
\hline Supplies & Need for regular supplies. \\
\hline \multirow[t]{4}{*}{ Equipment } & $\begin{array}{l}\text { High-technology equipment and } \\
\text { infrastructure needed. }\end{array}$ \\
\hline & Ease of acquisition. \\
\hline & $\begin{array}{l}\text { Number of different types of } \\
\text { equipment needed. }\end{array}$ \\
\hline & Maintenance needed. \\
\hline
\end{tabular}

\section{Delivery characteristics}

$\begin{array}{ll}\text { Facilities } & \text { Outreach services. } \\ \text { Facilities } & \text { First-level care. } \\ \text { Facilities } & \text { Hospital care. } \\ \text { Human resources } & \begin{array}{l}\text { Skill level required for service } \\ \text { provision. } \\ \text { Skill level required for staff } \\ \text { supervision. } \\ \text { Intensity of professional services in } \\ \text { terms of frequency or duration. } \\ \text { Management and planning } \\ \text { requirements. }\end{array} \\ \text { Communication and } & \begin{array}{l}\text { Dependence of delivery on } \\ \text { communication and transport } \\ \text { infrastructure. }\end{array}\end{array}$

\section{Government capacity requirements}

Regulation/legislation Need for regulation.

Management systems Need for sophisticated management systems.

Collaborative action Need for intersectoral action within government.

Need for partnership between government and external funding agencies.

\section{Usage characteristics}

\begin{tabular}{ll} 
Ease of use & Need for information and education. \\
Pre-existing demand & Need for promotion. \\
\hline Black market risk & $\begin{array}{l}\text { Need to prevent resale/ } \\
\text { counterfeiting. }\end{array}$ \\
\hline
\end{tabular}

\section{Step 6: Delphi round 2}

For this round, the participants received the questionnaires with the comments/suggestions of other panel members from the first round. However, this was modified for technical capacity, as stated above, and sent to the

\begin{tabular}{|c|c|c|}
\hline \multicolumn{2}{|l|}{ Characteristics } & \multirow{2}{*}{$\frac{\mathbf{N}(\%)^{*}}{5(55.6)}$} \\
\hline Gender & Female & \\
\hline \multirow[t]{2}{*}{ Age (years) } & $<50$ & 2 (22.2) \\
\hline & $>50$ & $7(77.8)$ \\
\hline \multirow[t]{2}{*}{ Professional group } & Ophthalmologist & $7(77.8)$ \\
\hline & Administrator & $2(22.2)$ \\
\hline \multirow[t]{3}{*}{ Primary function } & Clinician & $3(33.3)$ \\
\hline & Researcher & $3(33.3)$ \\
\hline & NGO administrator & 3 (33.3) \\
\hline \multirow[t]{4}{*}{ Type of institution } & Academic hospital & $2(22.2)$ \\
\hline & Non-academic hospital & $1(11,1)$ \\
\hline & Research institute & $3(33.3)$ \\
\hline & Eyecare NGO & $3(33.3)$ \\
\hline \multirow[t]{5}{*}{ Region of practice } & West Africa & $5(56)$ \\
\hline & East Africa & $2(22)$ \\
\hline & South Africa & $2(22)$ \\
\hline & Central Africa & $1(11)$ \\
\hline & Europe & $1(11)$ \\
\hline $\begin{array}{l}\text { Involved in national } \\
\text { policy making }\end{array}$ & Yes & $9(100)$ \\
\hline
\end{tabular}

The mean number of years of experience in eye health of the participants was $31.1 \pm 8.9$ (range 18-43) years.

*Some participants had multiple roles/had worked in multiple regions.

NGO, non-governmental organisation.

same expert panel using the same Likert scale and level of consensus.

\section{Step 7: analysis of Delphi round 2}

Only statements that achieved at least $70 \%$ consensus in the upper 50th percentile (Likert scores 1 and 2) in the second round were included in the final document. Where consensus was reached, the statements were adopted and formed the basis of the final document. Any minority views $(<70 \%$ consensus) did not form part of the adopted technical capacities but were documented. The technical capacities needed were mapped unto the WHO health system's building blocks. ${ }^{24}$

Patients were not involved in this study.

\section{RESULTS}

Composition of Delphi panel of experts

A total of 12 experts were contacted, nine of whom agreed to participate (table 2). No response was received from the other three invitees despite at least three contacts by email. All nine completed the two rounds of the Delphi survey.

\section{Delphi questionnaire development}

A total of 81 statements on the technical complexity of the WHO AFRO PEC package were developed from 
Table 3 Statements for each component of the WHO AFRO primary eye care package

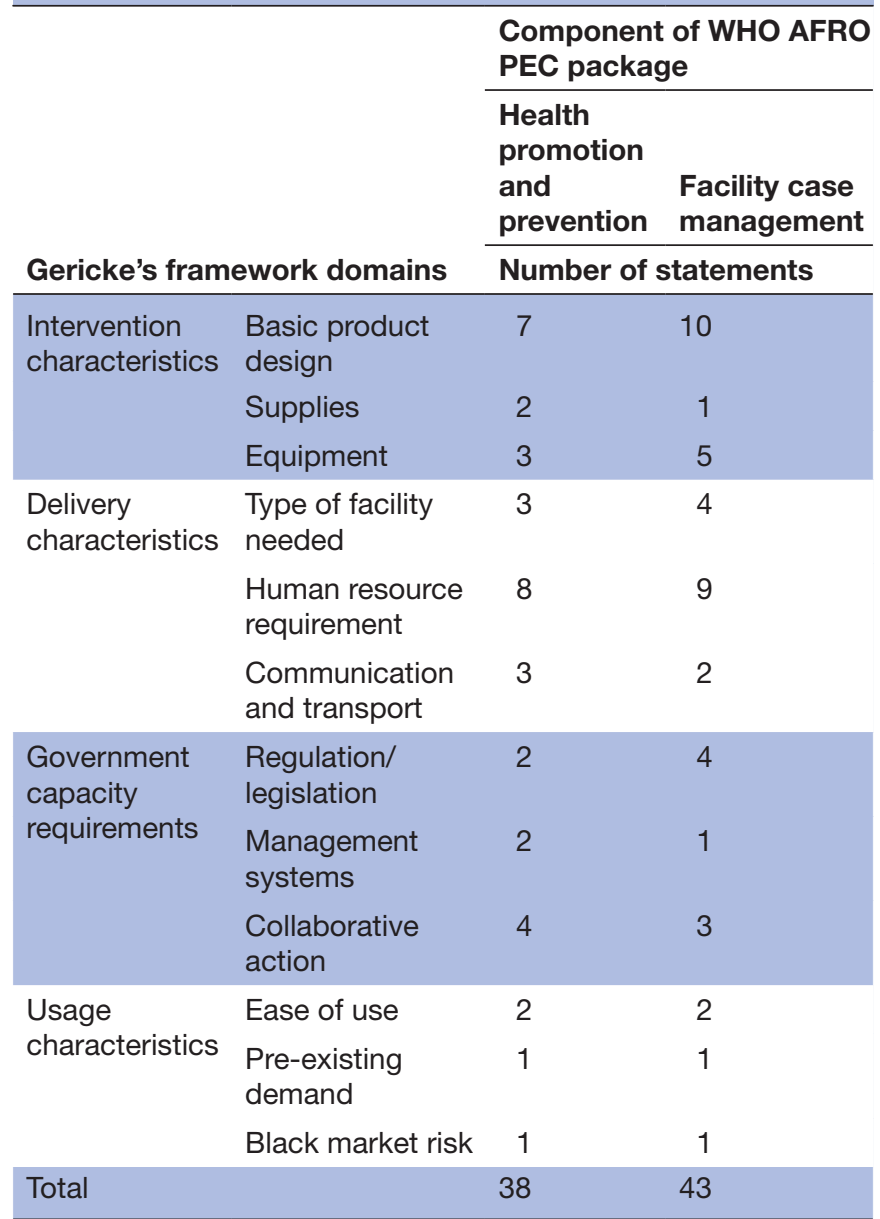

PEC, primary eye care; WHO AFRO, WHO Africa Office.

Gericke's framework, 38 for health promotion and 43 for facility-based case management (table 3).

In the first round, there was consensus in $84 \%$ of the statements with over $40 \%$ of the statements achieving $100 \%$ consensus (see online supplemental material: appendix 2). Based on comments from Delphi round 1 , six modifications were made in the health promotion component and seven in the facility case management component (see online supplemental material: appendix $3)$. The modified questionnaire formed the basis of technical capacity questionnaire for round two.

In the second round, four statements were deemed not to be applicable by $89 \%$ of participants and were removed. Consensus was achieved in $94 \%$ of the statements, with $62 \%$ achieving $100 \%$ consensus (online supplemental appendix 4). Results of the 34 statements on technical capacity for health promotion for which consensus was reached are shown in table $4 \mathrm{~A}$ with their respective Likert ratings, quartile and 50th percentile values. Results of the 40 statements on technical capacity for facility case management for which consensus was reached are shown in table $4 \mathrm{~B}$ with their respective Likert ratings, quartile and 50th percentile values. The top quartile shows the number and proportion of participants who strongly agreed with each of the statements, while the 50th percentile shows the number and proportion of participants that strongly agreed or agreed. The technical capacities needed were mapped unto the WHO health system's building blocks (table 5A and B).

\section{DISCUSSION}

Despite global and regional interest in PEC, 8102526 insights into the technical complexity of PEC and the technical capacities required to deliver it within PHC in SSA are lacking. The technical complexity was assessed using the well-known framework devised by Gericke, which complements the notion of institutional capacity in determining the feasibility of implementing or scaling up an intervention. ${ }^{16}$

In this study, we did not address other aspects of feasibility, such as legal and financial feasibility, and it may be argued that health financing is an important element to consider in low-resource countries, particularly in SSA, where less than half the countries have the minimum level of health financing of US $\$ 44$ per capita. ${ }^{27}$ However, nonfinancial resources are considered to be the critical factor limiting the implementation of health interventions. ${ }^{16}$

To the best of our knowledge, this is the first Delphi exercise to explore the technical capacities needed to implement the WHO AFRO PEC package in SSA.

Our study complements a recent systematic review on health systems preparedness for integration of services at the PHC level, ${ }^{28}$ and tools developed from our study will enable identification of elements of the health system at primary level that need to be strengthened to deliver PEC. This is important as the delivery of PEC can only be as effective as the PHC into which it is integrated. ${ }^{11}$ Having said this, it is important to recognise that eye health needs to be integrated into all levels of the health system to achieve universal coverage for eye health. ${ }^{10} 29$

Data to populate Gericke's framework were largely derived from a detailed review of the literature of PEC in SSA. Consensus on the capacities required to deliver PEC were reached after a two-round Delphi exercise by experts in public health for eye care in SSA: researchers, clinicians, policy makers and administrators. The primary function of panel members was evenly distributed between these three categories, and as all had been involved in policy development and service delivery for eye care in the region, they were experienced in what was feasible and what was not.

The literature review and the high consensus from the panel of experts increase the validity of the findings. In the first round, over four-fifths of the statements reached the predefined consensus, which implies that the majority of the technical complexities aligned with the views of the expert panel and their familiarity with the literature. In the second round, there was consensus on almost all the statements, with $100 \%$ consensus for almost two-thirds. This is to be expected, as the technical capacities were 
Table 4A Consensus statements on technical capacity for health promotion, with analysis of Likert scales

\section{Intervention characteristics}

Category/criteria

\begin{tabular}{|c|c|c|c|}
\hline \multirow{3}{*}{ Technical capacity needed (elements that need to be } & $\begin{array}{l}\text { Top } \\
\text { quartile }\end{array}$ & $\begin{array}{l}\text { 50th } \\
\text { percentile }\end{array}$ & \multirow{3}{*}{$\begin{array}{l}\text { Median } \\
\text { (IQR) }\end{array}$} \\
\hline & Likert 1 & Likert 2 & \\
\hline & $\%$ & $\%$ & \\
\hline
\end{tabular}

Basic product design

Stability: usable lifetime and risk of Posters that promote eye health. destruction

Durable posters are available.

$\begin{array}{lllll}7 & 77.8 & 9 & 100 & 1(1-1) \\ 4 & 44.4 & 9 & 100 & 1(1-2) \\ 5 & 55.6 & 9 & 100 & 1(1-2)\end{array}$

Standardisability: the degree to which an intervention can be standardised

Standardised posters available to deliver the same message per target group.

(IQR)

\begin{tabular}{|c|c|c|c|c|c|c|}
\hline & Posters available in the language of the community. & 6 & 66.7 & 7 & 77.8 & $1(1-2)$ \\
\hline & $\begin{array}{l}\text { Posters with self-explanatory graphics available for the } \\
\text { non-literate. }\end{array}$ & 8 & 88.9 & 9 & 100 & $1(1-1)$ \\
\hline & $\begin{array}{l}\text { Different types of posters available for different target } \\
\text { groups that are appropriately displayed. }\end{array}$ & 5 & 55.6 & 8 & 88.9 & $1(1-2)$ \\
\hline $\begin{array}{l}\text { Number of different types of } \\
\text { equipment needed. Maintenance } \\
\text { needed }\end{array}$ & $\begin{array}{l}\text { Health promotion materials available that are easy to } \\
\text { maintain. }\end{array}$ & 5 & 55.6 & 9 & 100 & $1(1-2)$ \\
\hline
\end{tabular}

A system for the easy procurement of health promotion $\quad \begin{array}{lllll}6 & 66.7 & 9 & 100 & 1(1-2)\end{array}$ materials.

\section{Delivery characteristics}

\section{Facilities}

Retail sector, outreach services, first-level care and hospital care

\begin{tabular}{|c|c|c|c|c|c|}
\hline $\begin{array}{l}\text { Health promotion in the community that includes young } \\
\text { children and their carers, persons with diabetes and the } \\
\text { elderly as their target audience. }\end{array}$ & 4 & 44.4 & 9 & 100 & $1(1-2)$ \\
\hline $\begin{array}{l}\text { Time, space and willingness to deliver opportunistic eye } \\
\text { health promotion to groups in the facility. }\end{array}$ & 7 & 77.8 & 8 & 88.9 & $1(1-1)$ \\
\hline $\begin{array}{l}\text { Time and the willingness to deliver opportunistic eye } \\
\text { health promotion to targeted individuals in the facility, for } \\
\text { example, persons with diabetes. }\end{array}$ & 5 & 55.6 & 7 & 77.8 & $1(1-2)$ \\
\hline
\end{tabular}

Human resources

Skill level required for service provision

$\begin{array}{lllllll}\begin{array}{l}\text { Staff skilled in communicating with community members. } \\ \text { f }\end{array} & 77.8 & 9 & 100 & 1(1-1) \\ \begin{array}{l}\text { Staff who are knowledgeable about community, eye } \\ \text { diseases and where to access care. }\end{array} & 7 & 77.8 & 9 & 100 & 1(1-1) \\ \begin{array}{l}\text { Village health workers resident in the community who are } \\ \text { able to deliver health promotion. }\end{array} & 6 & 66.7 & 9 & 100 & 1(1-2) \\ \begin{array}{l}\text { Facility-based staff who are able to deliver health } \\ \text { promotion. }\end{array} & 5 & 55.6 & 9 & 100 & 1(1-2) \\ \begin{array}{l}\text { Professionals to train staff on eye health promotion and } \\ \text { develop health promotion materials. }\end{array} & 9 & 100 & 9 & 100 & 1(1-1) \\ \begin{array}{l}\text { Supervisors who are able to supervise health promotion } \\ \text { activities including eye health. }\end{array} & 7 & 77.8 & 9 & 100 & 1(1-1)\end{array}$

Skill level required for staf supervision. Degree of supervision required

Intensity of professional services in terms of frequency or duration, for example, on schedule/periodic or continuous to accommodate emergencies

Need for managerial staff: management and planning requirements
Staff who regularly deliver health promotion on schedule. $\begin{array}{lllll}7 & 77.8 & 9 & 100 & 1(1-1)\end{array}$ Existing managerial staff who plan and organise target
audience to be sensitised in appropriate locations, for $5 \quad 55.6 \quad 9 \quad 100 \quad 1(1-2)$ example, carers of young children. 


\begin{tabular}{|c|c|c|c|c|c|c|}
\hline \multirow{2}{*}{ Category/criteria } & \multirow{2}{*}{$\begin{array}{l}\text { Technical capacity needed (elements that need to be } \\
\text { available) }\end{array}$} & \multirow{2}{*}{\multicolumn{2}{|c|}{$\begin{array}{l}\text { Top } \\
\text { quartile } \\
\text { Likert } 1\end{array}$}} & \multirow{2}{*}{\multicolumn{2}{|c|}{$\begin{array}{l}\text { 50th } \\
\text { percentile } \\
\text { Likert } 2 \\
\end{array}$}} & \multirow{2}{*}{$\begin{array}{l}\text { Mediar } \\
\text { (IQR) }\end{array}$} \\
\hline & & & & & & \\
\hline \multicolumn{7}{|l|}{ Communication and transport } \\
\hline $\begin{array}{l}\text { Dependence of delivery on } \\
\text { communication and transport } \\
\text { infrastructure: telephones and roads }\end{array}$ & Local transport infrastructure to visit communities. & 6 & 66.7 & 7 & 77.8 & $1(1-2)$ \\
\hline \multirow{2}{*}{$\begin{array}{l}\text { Need for substantial exchange } \\
\text { of information between different } \\
\text { sectors or levels of care }\end{array}$} & $\begin{array}{l}\text { Appropriate communication channels between the } \\
\text { community and frontline health facilities. }\end{array}$ & 8 & 88.9 & 9 & 100 & $1(1-1)$ \\
\hline & Staff who are able to communicate in the local language. & 9 & 100 & 9 & 100 & $1(1-1)$ \\
\hline
\end{tabular}

\section{Government capacity requirements}

\section{Regulation/legislation}

monitoring regulatory measures and enforcement of regulation
Health promotion materials that have been approved and $\quad \begin{array}{lllll}5 & 55.6 & 8 & 88.9 & 1(1-2)\end{array}$

endorsed by local regulatory authorities.

Eye health promotion activities that are recorded and $\quad \begin{array}{llllll}4 & 44.4 & 7 & 77.8 & 1(1-1)\end{array}$ monitored.

$\begin{array}{llllll}\text { National blindness prevention strategy that incorporates } & 9 & 88.9 & 8 & 88.9 & 1(1-1)\end{array}$ eye health promotion.

Need for sophisticated management Existing managerial structures for health promotion that $\quad \begin{array}{llllll}4 & 44.4 & 7 & 77.8 & 2(1-2)\end{array}$ systems and managerial staff. can be used to manage eye health promotion.

Level of management and planning requirements

\section{Collaborative action}

Need for intersectoral action within government. Need for partnership between government and civil society

Need for partnership between government and external funding agencies

$\begin{array}{llllll}\begin{array}{l}\text { Intersectoral activities within government or partnerships } \\ \text { between government and civil society. }\end{array} & 6 & 66.7 & 9 & 100 & 1(1-2) \\ \begin{array}{l}\text { Existing school health programmes. } \\ \text { Collaborations with NGOs to provide health promotion. }\end{array} & 1 & 33.3 & 7 & 77.8 & 2(1-2) \\ \begin{array}{l}\text { Collaboration between communities and frontline health } \\ \text { communities. }\end{array} & 7 & 77.8 & 9 & 100 & 1(1-1) \\ \end{array}$

4. Usage characteristics

Ease of use

Need for information and education Communication channels with community to inform target $9 \quad 88.9 \quad 9 \quad 100 \quad 1$ (1-1) population.

\begin{tabular}{|c|c|c|c|c|c|c|}
\hline Need for supervision & Staff to supervise health promotion activities. & 9 & 88.9 & 9 & 100 & $1(1-1)$ \\
\hline \multicolumn{7}{|l|}{ Pre-existing demand } \\
\hline Need for promotion & $\begin{array}{l}\text { Staff who engage in health promotion that includes the } \\
\text { uptake of eye care when required. }\end{array}$ & 9 & 88.9 & 9 & 100 & $1(1-1)$ \\
\hline
\end{tabular}

Black market risk

\begin{tabular}{|c|c|c|c|c|c|}
\hline $\begin{array}{l}\text { Need to prevent resale/ } \\
\text { counterfeiting }\end{array}$ & $\begin{array}{l}\text { Staff who engage and train traditional healers to identify } \\
\text { and refer eye conditions, with a system to support } \\
\text { training. }\end{array}$ & 7 & 77.8 & & $1(1-1)$ \\
\hline
\end{tabular}

Table 4B Consensus statements on technical capacity for facility case management, with analysis of Likert scales

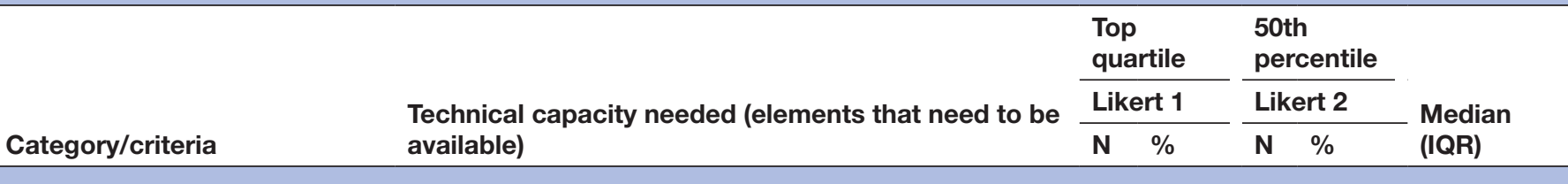

\section{Intervention characteristics}

Basic product design
Stability/ease of storage/ease of transport 
Table 4B Continued

\begin{tabular}{|c|c|c|c|c|c|c|}
\hline \multirow[b]{3}{*}{ Category/criteria } & \multirow{3}{*}{$\begin{array}{l}\text { Technical capacity needed (elements that need to be } \\
\text { available) }\end{array}$} & \multirow{2}{*}{\multicolumn{2}{|c|}{$\begin{array}{l}\text { Top } \\
\text { quartile }\end{array}$}} & \multirow{2}{*}{\multicolumn{2}{|c|}{$\begin{array}{l}\text { 50th } \\
\text { percentile } \\
\text { Likert } 2\end{array}$}} & \multirow{3}{*}{$\begin{array}{l}\text { Median } \\
\text { (IQR) }\end{array}$} \\
\hline & & & & & & \\
\hline & & $\mathbf{N}$ & $\%$ & $\mathbf{N}$ & $\%$ & \\
\hline & $\begin{array}{l}\text { Appropriate and secure storage for drugs and } \\
\text { consumables. }\end{array}$ & 8 & 88.9 & 9 & 100 & $1(1-1)$ \\
\hline & $\begin{array}{l}\text { Eye-drops that do not require cool storage should be } \\
\text { stocked. }\end{array}$ & 5 & 55.6 & 8 & 88.9 & $1(1-2)$ \\
\hline & Tetanus toxoid, which requires cool storage. & 6 & 66.7 & 8 & 88.9 & $1(1-2)$ \\
\hline & Topical antibiotic ointment does not require cold storage. & 6 & 66.7 & 8 & 88.9 & $1(1-2)$ \\
\hline & Sterile saline solution for eye irrigation is stable. & 4 & 44.4 & 7 & 77.8 & $1(1-2)$ \\
\hline & High dose vitamin A is stable. & 5 & 55.6 & 9 & 100 & $2(1-2)$ \\
\hline & $\begin{array}{l}\text { Injectable antibiotics, for ophthalmia neonatorum and } \\
\text { other conditions, may require cool storage }\end{array}$ & 4 & 44.4 & 7 & 77.8 & $1(1-2)$ \\
\hline & $\begin{array}{l}\text { Pre-existing PHC transport channels should be available } \\
\text { to transport PEC consumables. }\end{array}$ & 7 & 77.8 & 9 & 100 & $1(1-1)$ \\
\hline Standardisability & The WHO AFRO PEC package is standardised. & 6 & 66.7 & 9 & 100 & $1(1-2)$ \\
\hline Safety profile & $\begin{array}{l}\text { Staff who are trained/can be trained to deliver the } \\
\text { intervention correctly and not cause harm. }\end{array}$ & 8 & 88.9 & 9 & 100 & $1(1-1)$ \\
\hline \multicolumn{7}{|l|}{ Supplies } \\
\hline Need for regular supplies & $\begin{array}{l}\text { Medication supply system to support regular supply of } \\
\text { eye medications and consumables. }\end{array}$ & 8 & 88.9 & 9 & 100 & $1(1-1)$ \\
\hline \multicolumn{7}{|l|}{ Equipment } \\
\hline \multirow[t]{3}{*}{$\begin{array}{l}\text { High-technology equipment } \\
\text { and infrastructure needed }\end{array}$} & $\begin{array}{l}\text { Diagnostic equipment: Snellen distance visual acuity } \\
\text { chart; near visual acuity chart, torches and batteries. }\end{array}$ & 7 & 77.8 & 9 & 100 & $1(1-1)$ \\
\hline & $\begin{array}{l}\text { Adequate space to use appropriate, standardised visual } \\
\text { acuity charts. }\end{array}$ & 6 & 66.7 & 8 & 88.9 & $1(1-2)$ \\
\hline & Adequate space for counselling patients. & 8 & 88.9 & 9 & 100 & $1(1-1)$ \\
\hline $\begin{array}{l}\text { Number of different types of } \\
\text { equipment needed }\end{array}$ & One set of diagnostic equipment. & 6 & 66.7 & 8 & 88.9 & $1(1-2)$ \\
\hline Maintenance needed & System to maintain equipment in the facility. & 5 & 55.6 & 9 & 100 & $1(1-2)$ \\
\hline \multicolumn{7}{|l|}{ 2. Delivery characteristics } \\
\hline \multicolumn{7}{|l|}{ Facilities } \\
\hline First-level care & $\begin{array}{l}\text { Eye care services to manage uncomplicated eye } \\
\text { conditions. }\end{array}$ & 6 & 66.7 & 9 & 100 & $1(1-2)$ \\
\hline Hospital care & Referral hospital to manage complicated eye conditions. & 8 & 88.9 & 9 & 100 & $1(1-1)$ \\
\hline \multicolumn{7}{|l|}{ Human resources } \\
\hline \multirow[t]{3}{*}{$\begin{array}{l}\text { Skill level required for service } \\
\text { provision }\end{array}$} & $\begin{array}{l}\text { Staff able to make a diagnosis (take a history; measuring } \\
\text { visual acuity; basic eye examination). }\end{array}$ & 8 & 88.9 & 9 & 100 & $1(1-1)$ \\
\hline & $\begin{array}{l}\text { Staff able to manage some conditions, for example, eye } \\
\text { irrigation; remove foreign bodies; give IM injections. }\end{array}$ & 8 & 88.9 & 9 & 100 & $1(1-1)$ \\
\hline & $\begin{array}{l}\text { Staff able to identify which cases to refer and the level of } \\
\text { urgency. }\end{array}$ & 8 & 88.9 & 9 & 100 & $1(1-1)$ \\
\hline \multirow{2}{*}{$\begin{array}{l}\text { Skill level required for staff } \\
\text { supervision. Degree of } \\
\text { supervision required. }\end{array}$} & $\begin{array}{l}\text { Primary healthcare supervisors knowledgeable about eye } \\
\text { conditions and their management. }\end{array}$ & 6 & 66.7 & 9 & 100 & $1(1-2)$ \\
\hline & Regular supervision of PHC activities and PEC activities. & 6 & 66.7 & 9 & 100 & $1(1-2)$ \\
\hline $\begin{array}{l}\text { Frequency or duration } \\
\text { of services: for example, } \\
\text { on schedule/periodic or } \\
\text { continuous to accommodate } \\
\text { emergencies }\end{array}$ & $\begin{array}{l}\text { Staff trained in PEC always available to manage eye } \\
\text { conditions and emergencies. }\end{array}$ & 8 & 88.9 & 9 & 100 & $1(1-1)$ \\
\hline
\end{tabular}




\begin{tabular}{|c|c|c|c|c|c|c|}
\hline \multirow{2}{*}{ Category/criteria } & \multirow{2}{*}{$\begin{array}{l}\text { Technical capacity needed (elements that need to be } \\
\text { available) }\end{array}$} & \multirow{2}{*}{\multicolumn{2}{|c|}{$\begin{array}{l}\text { Top } \\
\text { quartile } \\
\text { Likert } 1\end{array}$}} & \multirow{2}{*}{\multicolumn{2}{|c|}{$\begin{array}{l}\text { 50th } \\
\text { percentile } \\
\text { Likert } 2 \\
\end{array}$}} & \multirow{2}{*}{$\begin{array}{l}\text { Median } \\
\text { (IQR) }\end{array}$} \\
\hline & & & & & & \\
\hline \multirow{3}{*}{$\begin{array}{l}\text { Management and planning } \\
\text { requirements. Need for } \\
\text { managerial staff }\end{array}$} & $\begin{array}{l}\text { Facility managers who supply consumables and plan } \\
\text { purchasing. }\end{array}$ & 6 & 66.7 & 9 & 100 & $1(1-2)$ \\
\hline & $\begin{array}{l}\text { Facility managers establish and maintain referral and } \\
\text { feedback between the } \mathrm{PH} \text { centre and eye care facilities. }\end{array}$ & 5 & 55.6 & 7 & 77.8 & $1(1-2)$ \\
\hline & $\begin{array}{l}\text { Managerial systems to coordinate staff rotations to } \\
\text { ensure daily facility coverage by trained PEC staff. }\end{array}$ & 7 & 77.8 & 9 & 100 & $1(1-1)$ \\
\hline \multicolumn{7}{|l|}{ Communication and transport } \\
\hline $\begin{array}{l}\text { Depends on delivery of } \\
\text { communication and transport } \\
\text { infrastructure }\end{array}$ & $\begin{array}{l}\text { Communication channels to maintain referral and } \\
\text { feedback mechanisms between the PH centre and } \\
\text { referral centre. }\end{array}$ & 6 & 66.7 & 9 & 100 & $1(1-2)$ \\
\hline
\end{tabular}

\section{Government capacity requirements}

\begin{tabular}{|c|c|c|c|c|c|c|}
\hline \multicolumn{7}{|l|}{ Regulation/legislation } \\
\hline Need for regulation & $\begin{array}{l}\text { National Essential Drug List includes appropriate } \\
\text { medication and equipment for eye care in } \mathrm{PH} \text { facilities. }\end{array}$ & 6 & 66.7 & 8 & 88.9 & $1(1-1)$ \\
\hline \multirow[t]{3}{*}{$\begin{array}{l}\text { Regulatory measures need to } \\
\text { be enforced and regulated }\end{array}$} & $\begin{array}{l}\text { System that regulates drug prescribing and dispensing by } \\
\text { appropriate staff. }\end{array}$ & 7 & 77.8 & 9 & 100 & $1(1-1)$ \\
\hline & Reporting systems for measles outbreaks. & 9 & 100 & 9 & 100 & $1(1-1)$ \\
\hline & Reporting system for ophthalmia neonatorum. & 7 & 77.8 & 9 & 100 & $1(1-1)$ \\
\hline $\begin{array}{l}\text { Sophisticated management } \\
\text { systems required }\end{array}$ & Managerial structures for $\mathrm{PH}$ care include eye care. & 7 & 77.8 & 9 & 100 & $1(1-1)$ \\
\hline \multicolumn{7}{|l|}{ Collaborative action } \\
\hline $\begin{array}{l}\text { Intersectoral action needed } \\
\text { within government, and } \\
\text { partnership between } \\
\text { government and civil society }\end{array}$ & $\begin{array}{l}\text { Intersectoral action within government or partnerships } \\
\text { between government and civil society. }\end{array}$ & 6 & 66.7 & 9 & 100 & $1(1-2)$ \\
\hline
\end{tabular}

\section{Usage characteristics}

\begin{tabular}{|c|c|c|c|c|c|c|}
\hline \multirow[t]{2}{*}{ Need for supervision } & Staff who make supervisory home visits. & 5 & 55.6 & 7 & 77.8 & $1(1-2)$ \\
\hline & Staff who supervise referrals to ensure compliance. & 4 & 44.4 & 8 & 88.9 & $1(1-2)$ \\
\hline \multicolumn{7}{|l|}{ Pre-existing demand } \\
\hline \multicolumn{7}{|l|}{ Black market risk } \\
\hline $\begin{array}{l}\text { Need to prevent resale/ } \\
\text { counterfeiting }\end{array}$ & $\begin{array}{l}\text { Staff who engage and train traditional healers to identify } \\
\text { and refer eye conditions, with a system to support } \\
\text { training. }\end{array}$ & 6 & 66.7 & 8 & 88.9 & $1(1-2)$ \\
\hline
\end{tabular}

IM, intramuscular; PEC, primary eye care; $\mathrm{PH}$, primary health; PHC, primary healthcare; WHO AFRO, WHO Africa Office.

derived from the technical complexities. For example, one of the technical complexities was 'hospital services are needed for referrals, severe cases, treatment failures, further investigations and management, as required', and the technical capacity derived was 'the availability of a referral hospital to manage complicated eye conditions'.

The human resource elements of the delivery characteristics domain for health promotion and facility-based management had perfect consensus. Human resources for health has been identified as a key component for the successful implementation of health interventions, ${ }^{30}$ which was emphasised in two review articles on PEC in SSA. ${ }^{11}{ }^{20}$ Government support and strong partnerships are crucial for the success of PEC in terms of sustainability and scaling up, as advocated in the WHO Global Action Plan (2014-2019) and for regulatory activities. ${ }^{10}$ Hence, the majority of elements in this domain had near perfect consensus. All the elements in the usage characteristics domain for health promotion had perfect consensus in the final round, emphasising the importance of creating 
Table 5 Gericke's framework: technical capacities needed to deliver (A) health promotion and (B) facility-based case management

\begin{tabular}{llll} 
Category & Criteria & $\begin{array}{l}\text { Technical capacity: elements that need to be } \\
\text { available }\end{array}$ & $\begin{array}{l}\text { Health system } \\
\text { building block }\end{array}$ \\
\hline
\end{tabular}

(A) Health promotion Intervention characteristics

\begin{tabular}{|c|c|c|c|}
\hline \multirow[t]{4}{*}{ Basic product design } & Stability & $\begin{array}{l}\text { Posters that promote eye health should be } \\
\text { available. Posters should be durable. }\end{array}$ & \multirow{4}{*}{$\begin{array}{l}\text { Infrastructure, } \\
\text { technology and } \\
\text { so on }\end{array}$} \\
\hline & \multirow[t]{3}{*}{ Standardisability } & $\begin{array}{l}\text { Standardised posters, delivering the same message } \\
\text { per target group. }\end{array}$ & \\
\hline & & Posters that are in the language of the community. & \\
\hline & & $\begin{array}{l}\text { Posters with self-explanatory graphics should be } \\
\text { available for the illiterate. }\end{array}$ & \\
\hline
\end{tabular}

Supplies and equipment Ease of acquisition

Number of different types of equipment needed

Maintenance needed
Easy system to procure health promotion materials. Infrastructure,

Different types of posters available for different target groups that are appropriately displayed. technology and so on

Health promotion materials available that are easy to maintain.

\section{Delivery characteristics}

Facilities

Outreach services

First-level care

First-level care
Intensity of professional services in terms of frequency or duration

$\begin{array}{ll}\text { Human resources } & \text { Skill level required for service } \\ \text { provision }\end{array}$

Health promotion that includes young children and their carers, persons with diabetes and the elderly as the target audience in the community.

Time and space available, and staff willing to deliver opportunistic eye health promotion to specific groups in the facility.

Time and space available, and staff willing to deliver opportunistic eye health promotion to specific individuals in the facility, for example, persons with diabetes.

\section{Staff skilled in communicating with community} members.

Health workforce

Staff who are knowledgeable about community, eye diseases and where to access care.

Village health workers resident in the community who are able to regularly deliver health promotion.

Facility-based staff who are able to regularly deliver health promotion.

Professionals to train staff on eye health promotion and develop health promotion materials.

\section{Skill level required for staff supervision}

Supervisors who are able to supervise health promotion activities including eye health.

Staff who regularly deliver health promotion on schedule.

Management and planning requirements

Existing managerial staff who plan and organise target audience to be sensitised in appropriate locations, for example, carers of young children.

$\begin{array}{ll}\text { Communication and } & \begin{array}{l}\text { Dependence of delivery on } \\ \text { communication and transport } \\ \text { transport }\end{array} \\ & \text { infrastructure }\end{array}$
Local transport infrastructure to visit communities. so on

Service delivery

Infrastructure, technology and

Appropriate communication channels between the Service community and PHC facilities. delivery/HMIS Staff who are able to communicate in the local Health language. workforce

\section{Government capacity requirements}


Table 5 Continued

\begin{tabular}{|c|c|c|c|}
\hline Category & Criteria & $\begin{array}{l}\text { Technical capacity: elements that need to be } \\
\text { available }\end{array}$ & $\begin{array}{l}\text { Health system } \\
\text { building block }\end{array}$ \\
\hline \multirow[t]{2}{*}{ Regulation/legislation } & \multirow[t]{2}{*}{ Need for regulation/legislation } & $\begin{array}{l}\text { Health promotion materials that have been } \\
\text { approved and endorsed by local regulatory } \\
\text { authorities. }\end{array}$ & \multirow[t]{2}{*}{$\begin{array}{l}\text { Governance } \\
\text { and leadership }\end{array}$} \\
\hline & & $\begin{array}{l}\text { A national blindness prevention strategy that } \\
\text { incorporates eye health promotion. }\end{array}$ & \\
\hline Management systems & $\begin{array}{l}\text { Need for management } \\
\text { systems }\end{array}$ & $\begin{array}{l}\text { Existing managerial structures for health promotion } \\
\text { can be used. Eye health promotion activities that } \\
\text { are recorded and monitored. }\end{array}$ & HMIS \\
\hline \multirow[t]{4}{*}{ Collaborative action } & \multirow{2}{*}{$\begin{array}{l}\text { Need for intersectoral action } \\
\text { within government }\end{array}$} & $\begin{array}{l}\text { Intersectoral activities within government or } \\
\text { partnerships between government and civil society. }\end{array}$ & $\begin{array}{l}\text { Governance } \\
\text { and leadership }\end{array}$ \\
\hline & & Existing school health programmes. & Service delivery \\
\hline & \multirow{2}{*}{$\begin{array}{l}\text { Need for partnership between } \\
\text { government and external } \\
\text { funding agencies }\end{array}$} & $\begin{array}{l}\text { Collaborations with NGOs to provide health } \\
\text { promotion. }\end{array}$ & \multirow[t]{2}{*}{$\begin{array}{l}\text { Governance } \\
\text { and leadership }\end{array}$} \\
\hline & & $\begin{array}{l}\text { Collaboration between communities and PHC } \\
\text { facilities is required. }\end{array}$ & \\
\hline \multicolumn{4}{|l|}{ Usage characteristics } \\
\hline \multirow[t]{2}{*}{ Ease of use } & \multirow{2}{*}{$\begin{array}{l}\text { Need for information } \\
\text { and education/need for } \\
\text { supervision }\end{array}$} & $\begin{array}{l}\text { Communication channels with community that are } \\
\text { available to inform target population. }\end{array}$ & Service delivery \\
\hline & & $\begin{array}{l}\text { Staff who are available to supervise health } \\
\text { promotion activities. }\end{array}$ & $\begin{array}{l}\text { Governance } \\
\text { and leadership }\end{array}$ \\
\hline Pre-existing demand & Need for promotion & $\begin{array}{l}\text { Staff who are able to engage in eye health } \\
\text { promotion to target audience to significantly } \\
\text { increase demand. }\end{array}$ & Service delivery \\
\hline Black market risk & $\begin{array}{l}\text { Need to prevent resale/ } \\
\text { counterfeiting }\end{array}$ & $\begin{array}{l}\text { Staff who are able and willing to engage with } \\
\text { traditional healers and train them to identify and } \\
\text { refer eye conditions. A system that supports this } \\
\text { training. }\end{array}$ & \\
\hline
\end{tabular}

\section{(B) Facility-based case management}

\section{Intervention characteristics}

Basic product design Stability and ease of storage Torches should be available. They can be solar powered and are stable.

Appropriate and secure storage for drugs and consumables should be available.

Eye-drops that do not require cool storage should be stocked.

Tetanus toxoid will require cool storage and should be available from facility childhood immunisation activities.

Topical antibiotic ointment does not require cold storage and should be available.

Injectable antibiotics for ophthalmia neonatorum may require cool storage but should be available to treat other conditions.

Sterile saline solution for eye irrigation is stable and should be available.

High dose vitamin $A$ is stable and should be available from maternal and child health activities.

Ease of transport Pre-existing PHC transport channels should be available to transport PEC consumables. 
Table 5 Continued

\begin{tabular}{llll}
\hline Category & Criteria & $\begin{array}{l}\text { Technical capacity: elements that need to be } \\
\text { available }\end{array}$ & $\begin{array}{l}\text { Health system } \\
\text { building block }\end{array}$ \\
\hline Standardisability & $\begin{array}{l}\text { The WHO AFRO PEC package is standardised and } \\
\text { can be available in all primary care facilities. }\end{array}$ & $\begin{array}{l}\text { Available staff who are trained/can be trained to } \\
\text { deliver the intervention correctly so as not to cause } \\
\text { harm. }\end{array}$ & $\begin{array}{l}\text { Health } \\
\text { workforce }\end{array}$ \\
Supplies and equipment & Need for regular supplies & $\begin{array}{l}\text { A medication supply system that can support } \\
\text { the regular supply of eye medications and } \\
\text { consumables. }\end{array}$ & $\begin{array}{l}\text { Infrastructure, } \\
\text { technology and } \\
\text { so on }\end{array}$
\end{tabular}

High-technology equipment Diagnostic equipment is available: Snellen distance and infrastructure needed visual acuity chart; near visual acuity chart, torches and batteries.

\begin{tabular}{|c|c|c|c|}
\hline & & \multicolumn{2}{|l|}{$\begin{array}{l}\text { Adequate space to support the use of appropriate } \\
\text { and standardised visual acuity charts. }\end{array}$} \\
\hline & & \multicolumn{2}{|l|}{$\begin{array}{l}\text { Adequate space for counselling patients should be } \\
\text { available. }\end{array}$} \\
\hline & $\begin{array}{l}\text { Number of different types of } \\
\text { equipment needed }\end{array}$ & \multicolumn{2}{|l|}{ The availability of one set of diagnostic equipment. } \\
\hline & Maintenance needed & \multicolumn{2}{|l|}{$\begin{array}{l}\text { An available system for the maintenance of facility } \\
\text { equipment. }\end{array}$} \\
\hline \multicolumn{4}{|c|}{ Delivery characteristics } \\
\hline Facilities & First-level care & $\begin{array}{l}\text { The availability of eye care services to manage } \\
\text { uncomplicated eye conditions. }\end{array}$ & \multirow[t]{2}{*}{ Service delivery } \\
\hline Facilities & Hospital care & $\begin{array}{l}\text { The availability of a referral hospital to manage } \\
\text { complicated eye conditions. }\end{array}$ & \\
\hline \multirow[t]{9}{*}{ Human resources } & \multirow[t]{3}{*}{$\begin{array}{l}\text { Skill level required for service } \\
\text { provision }\end{array}$} & $\begin{array}{l}\text { Staff who are able to make a diagnosis (eliciting } \\
\text { a history; measuring visual acuity; basic eye } \\
\text { examination). }\end{array}$ & \\
\hline & & $\begin{array}{l}\text { Staff who are able to manage some conditions, for } \\
\text { example, eye irrigation; removal of foreign bodies; } \\
\text { give IM injections (tetanus toxoid; antibiotics) }\end{array}$ & \\
\hline & & $\begin{array}{l}\text { Staff who are able to identify which cases to refer } \\
\text { and the level of urgency. }\end{array}$ & \\
\hline & \multirow[t]{2}{*}{$\begin{array}{l}\text { Skill level required for staff } \\
\text { supervision }\end{array}$} & $\begin{array}{l}\text { PHC supervisors who are knowledgeable about eye } \\
\text { conditions and their management. }\end{array}$ & \multirow[t]{2}{*}{$\begin{array}{l}\text { Governance } \\
\text { and leadership }\end{array}$} \\
\hline & & $\begin{array}{l}\text { Supervisors who regularly supervise PHC activities } \\
\text { and can supervise PEC activities. }\end{array}$ & \\
\hline & $\begin{array}{l}\text { Intensity of professional } \\
\text { services in terms of } \\
\text { frequency or duration }\end{array}$ & $\begin{array}{l}\text { Staff trained in PEC who are available continuously } \\
\text { to manage eye conditions, especially emergencies. }\end{array}$ & Service delivery \\
\hline & \multirow[t]{3}{*}{$\begin{array}{l}\text { Management and planning } \\
\text { requirements }\end{array}$} & $\begin{array}{l}\text { Existing managerial facility staff who are able to } \\
\text { manage the supply of consumables and plan } \\
\text { purchasing. }\end{array}$ & \multirow[t]{3}{*}{$\begin{array}{l}\text { Governance } \\
\text { and leadership }\end{array}$} \\
\hline & & $\begin{array}{l}\text { Existing managerial facility staff who are able } \\
\text { to establish and maintain referral and feedback } \\
\text { mechanisms between the PHC facility and eye } \\
\text { department/clinic. }\end{array}$ & \\
\hline & & $\begin{array}{l}\text { Existing managerial systems to coordinate staff } \\
\text { rotations to ensure daily facility coverage by trained } \\
\text { PEC staff. }\end{array}$ & \\
\hline
\end{tabular}


Table 5 Continued

\begin{tabular}{lll}
\hline Category & Criteria & $\begin{array}{l}\text { Technical capacity: elements that need to be } \\
\text { available }\end{array}$ \\
$\begin{array}{lll}\text { Communication and } \\
\text { transport }\end{array}$ & $\begin{array}{l}\text { Dependence of delivery on } \\
\text { communication and transport } \\
\text { infrastructure }\end{array}$ & $\begin{array}{l}\text { Communication channels to maintain referral and } \\
\text { feedback mechanisms between the PHC facility } \\
\text { and the referral centre. }\end{array}$ \\
& $\begin{array}{l}\text { Transport between the PHC facility and the referral } \\
\text { centre. }\end{array}$
\end{tabular}

\section{Government capacity requirements}

\begin{tabular}{|c|c|c|c|}
\hline Regulation/legislation & Need for regulation. & $\begin{array}{l}\text { Appropriate medication and equipment need to } \\
\text { be on the national essential drug list to facilitate } \\
\text { availability. }\end{array}$ & $\begin{array}{l}\text { Governance } \\
\text { and leadership }\end{array}$ \\
\hline \multirow[t]{3}{*}{ Management systems } & \multirow[t]{3}{*}{$\begin{array}{l}\text { Need for sophisticated } \\
\text { management systems }\end{array}$} & $\begin{array}{l}\text { A system that regulates drug prescription and } \\
\text { dispensing by appropriate staff. }\end{array}$ & \\
\hline & & $\begin{array}{l}\text { Communication channels to report measles } \\
\text { outbreaks to relevant authorities. }\end{array}$ & \\
\hline & & $\begin{array}{l}\text { Existing managerial structures for } \mathrm{PHC} \text { that can be } \\
\text { used to manage PEC. }\end{array}$ & HMIS \\
\hline Collaborative action & $\begin{array}{l}\text { Need for intersectoral } \\
\text { action within government } \\
\text { or partnership between } \\
\text { government and external } \\
\text { funding agencies. }\end{array}$ & $\begin{array}{l}\text { Availability of intersectoral action within government } \\
\text { or partnerships between government and civil } \\
\text { society. }\end{array}$ & $\begin{array}{l}\text { Governance } \\
\text { and leadership }\end{array}$ \\
\hline \multirow[t]{2}{*}{ Ease of use } & \multirow{2}{*}{$\begin{array}{l}\text { Need for information } \\
\text { and education/need for } \\
\text { supervision }\end{array}$} & $\begin{array}{l}\text { Staff who are available to make supervisory home } \\
\text { visits. }\end{array}$ & \multirow[t]{2}{*}{$\begin{array}{l}\text { Governance } \\
\text { and leadership }\end{array}$} \\
\hline & & $\begin{array}{l}\text { Staff who are able to supervise referrals to } \\
\text { secondary centres to ensure compliance. }\end{array}$ & \\
\hline Pre-existing demand & Need for promotion & $\begin{array}{l}\text { Staff who are able to engage in eye health } \\
\text { promotion to target audience. }\end{array}$ & \multirow[t]{2}{*}{ Service delivery } \\
\hline Black market risk & $\begin{array}{l}\text { Need to prevent resale/ } \\
\text { counterfeiting }\end{array}$ & $\begin{array}{l}\text { Staff who are able and willing to engage with } \\
\text { traditional healers and train them to identify and } \\
\text { refer eye conditions. A system that supports this } \\
\text { training. }\end{array}$ & \\
\hline
\end{tabular}

HMIS, Health Management Information Systems; IM, intramuscular; NGOs, non-governmental organisations; PEC, primary eye care; PHC, primary healthcare; WHO AFRO, WHO Africa Office.

demand $^{31}$ and reducing the impact of harmful traditional eye practices. $^{32}$

The WHO health systems building blocks were mapped unto appropriate elements of the final technical capacity profile for PEC. Adopting a health systems strengthening approach in which eye health is included in all the building blocks will amplify the benefits of the intervention $^{33}$ and promote sustainability.

The technical capacity frameworks for delivering the WHO AFRO PEC package were developed using data and experts from a range of SSA countries. However, caution is needed in extrapolating the findings from the Delphi exercise in this study to all WHO AFRO countries, as local adaptation of the WHO AFRO package may be required and hence the capacities needed to address varying eye health needs in different settings and PHC contexts. For example, the cadres providing PHC are likely to vary, as is the availability of informal health providers.

There are several strengths and limitations of this study. The selection of the expert panel is a crucial part of the Delphi process as the output is based on their expert opinion. ${ }^{34}$ Our expert panel was a non-random sample, and this may have led to hidden biases as the participants may not be representative of all the experts with the predetermined inclusion criteria. Indeed, almost half of the participants were from West Africa, but the majority had worked in agencies that had oversight of sub-Saharan African eye healthcare. Another limitation is that although all panel members had relevant expertise and experience, PHC practitioners were not included, as the focus was on eye care, which the majority of PHC practitioners in Africa would have little experience of. 
One of the disadvantages of the Delphi consensus is that it is provides low-level evidence (expert opinion) ${ }^{35}$ as randomised controlled trials provide the highest level evidence; only a few trials have been undertaken on PEC in low-income and middle-income countries. ${ }^{36}$ However, the Delphi method is useful when there are limited data to guide clinical practice. In this study, the framework for the questionnaires was a validated framework that has been used to assess the non-financial inputs needed to implement new interventions with a view to scaling up. ${ }^{16}$ Our study used anonymity, which is an inherent strength of the Delphi process, which helped avoid undue influence by any members and the efficient harnessing of expert opinion from diversely geographically dispersed experts $^{3738}$ from East, West, Southern Africa and the UK. Another strength of our study is the low non-response bias. Although 12 experts were invited to participate, nine agreed and all completed both Delphi rounds.

This study has generated the first technical feasibility capacity profile for PEC to guide countries wishing to implement PEC, based on an internationally accepted feasibility framework, a review of the PEC literature and expert opinion. However, there was limited published evidence on PEC in SSA from which the technical capacities were derived. As more high-level evidence studies on PEC in SSA are conducted, the document will need to be revised.

\section{Future research}

Mixed-methods data collection tools for different participant groups (village health workers, PHC workers, heads of facilities and district supervisors) in Nigeria have been developed based on our capacity frameworks, that is, structured questionnaires, observational check lists and topic guides for in-depth interviews. A number of PHC facilities in Southeast Nigeria have been assessed using these tools, and a gap analysis will be conducted. The capacity of PHC to deliver eye care has sparked passionate debates, ${ }^{29}$ and robust studies on the effectiveness of PEC will be needed in the future.

\section{CONCLUSIONS}

Consensus was reached on the technical capacities that need to be in place to deliver the WHO AFRO PEC package using a Delphi exercise. Based on this document, study tools have been developed to assess health system gaps in PHC in Nigeria. Countries or health units wishing to implement PEC using the WHO AFRO PEC package should address any capacity gaps before implementing or scaling up this intervention.

\section{Author affiliations}

${ }^{1}$ International Centre for Eye Health, London School of Hygiene \& Tropical Medicine, London, UK

${ }^{2}$ Department of Ophthalmology, University of Nigeria Faculty of Medical Sciences, Enugu, Nigeria

${ }^{3}$ Global Health and Development, London School of Hygiene \& Tropical Medicine Faculty of Public Health and Policy, London, UK
${ }^{4}$ Rwanda Institute of Ophthalmology, Kigali, Rwanda

${ }^{5}$ African Vision Research Institute, Durban, South Africa

${ }^{6}$ Department of Ophthalmology, University of Calabar, Calabar, Nigeria

${ }^{7}$ Sight Savers International, Kaduna, Nigeria

${ }^{8}$ Department of Ophthalmology, Baze University, Abuja, Nigeria

${ }^{9}$ Operation Eyesight, Accra, Ghana

Acknowledgements We would like to acknowledge the support of David MacCleod, Statistician at the London School of Hygiene \& Tropical Medicine for guidance in developing the Delphi questionnaire and Renee du Toit, independent eye health consultant, South Africa, for her input into the analysis of the Delphi questionnaire.

Contributors AA, HEDB and CEG were responsible for the design and conception of the work. AF, WM, HBF, RU, FE, SI, FK and BW contributed to the acquisition of data. AA drafted the work. AA, HEDB and CEG substantially revised it. All authors made some input into the final version and have approved the submitted version.

Funding This research was made possible by a grant from the Queen Elizabeth Diamond Jubilee Trust, UK, coordinated through the Commonwealth Eye health Consortium, UK. Grant number EMODXN1M6.

Disclaimer The funding organisations had no role in the design and conduct of the research.

Competing interests None declared.

Patient consent for publication Not required.

Ethics approval This was part of a wider study on primary eye care, and ethical approval was obtained from the Ethics Committees of the Federal Ministry of Health, Nigeria (NHREC Approval Number NHREC/01/01/2007-12/03/2018) and the London School of Hygiene \& Tropical Medicine (LSHTM Ethics Ref: 14624).

Provenance and peer review Not commissioned; externally peer reviewed.

Data availability statement All data relevant to the study are included in the article or uploaded as supplemental information.

Supplemental material This content has been supplied by the author(s). It has not been vetted by BMJ Publishing Group Limited (BMJ) and may not have been peer-reviewed. Any opinions or recommendations discussed are solely those of the author(s) and are not endorsed by BMJ. BMJ disclaims all liability and responsibility arising from any reliance placed on the content. Where the content includes any translated material, BMJ does not warrant the accuracy and reliability of the translations (including but not limited to local regulations, clinical guidelines, terminology, drug names and drug dosages), and is not responsible for any error and/or omissions arising from translation and adaptation or otherwise.

Open access This is an open access article distributed in accordance with the Creative Commons Attribution Non Commercial (CC BY-NC 4.0) license, which permits others to distribute, remix, adapt, build upon this work non-commercially, and license their derivative works on different terms, provided the original work is properly cited, appropriate credit is given, any changes made indicated, and the use is non-commercial. See: http://creativecommons.org/licenses/by-nc/4.0/.

ORCID iDs

Ada Aghaji http://orcid.org/0000-0003-1308-447X

Helen E D Burchett http://orcid.org/0000-0002-8380-2476

\section{REFERENCES}

1 International Agency for the Prevention of Blindness. Vision atlas, 2016. Available: http://atlasiapborg/ [Accessed 23 Apr 2019].

2 Bourne RRA, Flaxman SR, Braithwaite T, et al. Magnitude, temporal trends, and projections of the global prevalence of blindness and distance and near vision impairment: a systematic review and metaanalysis. Lancet Glob Health 2017;5:e888-97.

3 Gray Z, Ackland P. Cataract surgical coverage. an important indicator for eye health and for monitoring progress towards universal health coverage. International Agency for the Prevention of Blindness 2015;2015.

4 Kimani K, Lindfield R, Senyonjo L, et al. Prevalence and causes of ocular morbidity in Mbeere district, Kenya. Results of a populationbased survey. PLoS One 2013;8:e70009.

5 Senyonjo L, Lindfield R, Mahmoud A, et al. Ocular morbidity and health seeking behaviour in Kwara state, Nigeria: implications for delivery of eye care services. PLoS One 2014;9:e104128. 
6 Murthy G, Raman U. Perspectives on primary eye care. Community Eye Health 2009;22:10-11.

7 Andriamanjato $\mathrm{H}$, Mathenge W, Kalua K, et al. Task shifting in primary eye care: how sensitive and specific are common signs and symptoms to predict conditions requiring referral to specialist eye personnel? Hum Resour Health 2014;12:S3.

8 Graham R. Facing the crisis in human resources for eye health in sub-Saharan Africa. Community Eye Health 2017;30:85.

9 Aghaji AE, Gilbert C, Ihebuzor N, et al. Strengths, challenges and opportunities of implementing primary eye care in Nigeria. BMJ Glob Health 2018;3:e000846.

10 World Health Organization. Universal eye health: a global action plan 2014-2019, 2013. Available: http://www.who.int/blindness. AP2014 19_English pdf

11 Courtright P, Seneadza A, Mathenge W, et al. Primary eye care in sub-Saharan African: do we have the evidence needed to scale up training and service delivery? Ann Trop Med Parasitol 2010;104:361-7.

12 World Health Organisation. Report of the expert group meeting to assess and validate a package for eye health interventions at the primary level for the African region, 2012.

13 World Health Organisation Africa Region. Primary eye care training manual-A course to strengthen the capacity of health personnel to manage eye patients at primary-level health facilities in the African region. Brazzaville: World Health organization Regional Office for Africa, 2018. https://www.afro.who.int/publications/primary-eyecare-training-manual

14 Tesema AG, Ajisegiri WS, Abimbola S, et al. How well are non-communicable disease services being integrated into primary health care in Africa: a review of progress against World Health Organization's African regional targets. PLOS One 2020;15:e0240984.

15 Snowdon W, Lawrence M, Schultz J, et al. Evidence-informed process to identify policies that will promote a healthy food environment in the Pacific Islands. Public Health Nutr 2010;13:886-92.

16 Gericke CA, Kurowski C, Ranson MK, et al. Intervention complexity: a conceptual framework to inform priority-setting in health. Bull World Health Organ 2005;83:285-93.

17 Hsu C-C, Sandford BA. The Delphi technique: making sense of consensus. Prac Asses, Res Eval 2007:12:1-8.

18 J. Skulmoski G, T. Hartman F, Krahn J. The Delphi method for graduate research. J Inform Tech Educ: Res 2007;6:001-21.

19 Wu F, Khlangwiset P. Evaluating the technical feasibility of aflatoxin risk reduction strategies in Africa. Food Addit Contam Part A Chem Anal Control Expo Risk Assess 2010;27:658-76.

20 du Toit R, Faal HB, Etya'ale D, et al. Evidence for integrating eye health into primary health care in Africa: a health systems strengthening approach. BMC Health Serv Res 2013;13:102.
21 Dudovskiy J. Snowballing, 2019. Available: https://researchmethodologynet/sampling-in-primary-data-collection/snowballsampling/ [Accessed 23 Jan 2019]

22 Hsu C-C, Sandford BA. The Delphi technique: making sense of consensus. Pract Assess, Res, Evaluat 2007;12:10.

23 Guan L, Gao P, Liu S, et al. Development of a global health bachelor curriculum in China: a Delphi study. BMJ Open 2019;9:e023893.

24 World Health Organization. Everybody's business-strengthening health systems to improve health outcomes: WHO's framework for action, 2007.

25 Bright T, Kuper H, Macleod D, et al. Population need for primary eye care in Rwanda: a national survey. PLoS One 2018;13:e0193817.

26 Lilian RR, Railton J, Schaftenaar E, et al. Strengthening primary eye care in South Africa: an assessment of services and prospective evaluation of a health systems support package. PLoS One 2018;13:e0197432.

27 World Health Organization. State of health financing in the African region, 2013.

28 Topp SM, Abimbola S, Joshi R, et al. How to assess and prepare health systems in low- and middle-income countries for integration of services-a systematic review. Health Policy Plan 2018;33:298-312.

29 Blanchet K, Gilbert C, de Savigny D. Rethinking eye health systems to achieve universal coverage: the role of research. Br J Ophthalmol 2014;98:1325-8.

30 Chol C, Negin J, Garcia-Basteiro A, et al. Health system reforms in five sub-Saharan African countries that experienced major armed conflicts (wars) during 1990-2015: a literature review. Glob Health Action 2018;11:1517931.

31 Müller A, Murenzi J, Mathenge W, et al. Primary eye care in Rwanda: gender of service providers and other factors associated with effective service delivery. Trop Med Int Health 2010;15:529-33.

32 Adekoya BJ, Ayanniyi AA, Adepoju FG, et al. Minimising corneal scarring from the use of harmful traditional eye remedies in developing countries. Nig Q J Hosp Med 2012;22:138-41.

33 Blanchet K, Lindfield R. Health systems and eye care: a way forward. IAPB Briefing Papers, 2010

34 Shah K, Naidoo K, Loughman J. Development of socially responsive competency frameworks for ophthalmic technicians and optometrists in Mozambique. Clin Exp Optom 2016;99:173-82.

35 Hohmann E, Brand JC, Rossi MJ. Expert opinion is necessary: Delphi panel methodology facilitates a scientific approach to consensus. Elsevier, 2018.

36 Rowe AK, de Savigny D, Lanata CF, et al. How can we achieve and maintain high-quality performance of health workers in low-resource settings? Lancet 2005;366:1026-35.

37 WHO. Decision-making for guideline development at WHO. In: WHO handbook for guideline development [online]. 2nd edn. Geneva: World Health Organization, 2014: 201-14.

38 Ferri CP, Prince M, Brayne C, et al. Global prevalence of dementia: a Delphi consensus study. Lancet 2005;366:2112-7. 